\title{
Quantitative genetic analysis of methylxanthines and phenolic compounds in mate progenies
}

\author{
Euclides Lara Cardozo Junior(1), Carmen Maria Donaduzzi(1), Osvaldo Ferrarese-Filho(2), \\ Juliana Cristhina Friedrich ${ }^{(1)}$, Adriana Gonela ${ }^{(3)}$ and José Alfredo Sturion ${ }^{(4)}$
}

\begin{abstract}
(1)Universidade Paranaense, Departamento de Farmácia, Avenida Parigot de Souza, № 3.636, CEP 85903-170 Toledo, PR. E-mail: euclideslc@unipar.br, donaduzzicarmem@uol.com.br, julianafriedrich@ibest.com.br (2)Universidade Estadual de Maringá (UEM), Departamento de Bioquímica, Avenida Colombo, № 5.790, CEP 87020-900 Maringá, PR. E-mail: oferrarese@uem.br (3)UEM, Departamento de Agronomia. E-mail: agonela@uem.br (4)Embrapa Florestas, Estrada da Ribeira Km 111, CEP 83411-000 Colombo, PR. E-mail: sturion@cnpf.embrapa.br
\end{abstract}

\begin{abstract}
The objective of this work was to determine the contents of methylxanthines, caffeine and theobromine, and phenolic compounds, chlorogenic and caffeic acids, in 51 mate progenies (half-sib families) and estimate the heritability of genetic parameters. Mate progenies were from five Brazilian municipalities: Pinhão, Ivaí, Barão de Cotegipe, Quedas do Iguaçu, and Cascavel. The progenies were grown in the Ivaí locality. The contents of the compounds were obtained by high performance liquid chromatography (HPLC). The estimation of genetic parameters by the restricted maximum likelihood (REML) and the prediction of genotypic values via best linear unbiased prediction (BLUP) were obtained by the Selegen - REML/BLUP software. Caffeine $(0.248-1.663 \%)$ and theobromine $(0.106-0.807 \%)$ contents were significantly different $(\mathrm{p}<0.05)$ depending on the region of origin, with high individual heritability $\left(\hat{\mathrm{h}}^{2}>0.5\right)$. The two different progeny groups determined for chlorogenic (1.365-2.281\%) and caffeic (0.027-0.037\%) acid contents were not significantly different $(\mathrm{p}<0.05)$ depending on the locality of origin. Individual heritability values were low to medium for chlorogenic $\left(\hat{\mathrm{h}}^{2}<0.4\right)$ and caffeic acid $\left(\hat{\mathrm{h}}^{2}<0.3\right)$. The content of the compounds and the values of genetic parameters could support breeding programs for mate.
\end{abstract}

Index terms: Ilex paraguariensis, caffeine, caffeic acid, chlorogenic acid, genetic parameters, theobromine.

\section{Análise genética quantitativa de metilxantinas e compostos fenólicos em progênies de erva-mate}

\begin{abstract}
Resumo - O objetivo deste trabalho foi determinar o teor de metilxantinas, cafeína e teobromina, e de compostos fenólicos, ácido clorogênico e ácido cafeico, em 51 progênies de erva-mate e estimar componentes de variância e herdabilidade. As progênies de erva-mate eram oriundas de cinco municipios brasileiros: Pinhão, Ivaí, Barão do Cotegipe, Quedas do Iguaçu e Cascavel. Essas progênies foram cultivadas na localidade de Ivaí. O conteúdo dos compostos foi obtido por cromatografia líquida de alta eficiência (CLAE). Na estimativa dos componentes da variância e dos parâmetros genotípicos, utilizou-se a metodologia de modelos mistos para a obtenção da melhor predição linear não viciada (BLUP) dos efeitos genotípicos e o processo da máxima verossimilhança restrita (REML), processados pelo programa Selegen - REML/BLUP. Os conteúdos de cafeína $(0,248-1,663 \%)$ e teobromina $(0,106-0.807 \%)$ foram significativamente $(\mathrm{p}<0,05)$ diferentes em relação à localidade de origem, com elevada herdabilidade individual $\left(\hat{\mathrm{h}}^{2}>0,5\right)$. Foram determinados dois diferentes grupos de progênie para ácido clorogênico $(1,365-2,281 \%)$ e ácido cafeico $(0,027-0,037 \%)$, e seu conteúdo não foi significativamente diferente $(\mathrm{p}<0,05)$ em relação à localidade de origem. Os valores de herdabilidade individual foram de baixos a médios para ácido clorogênico $\left(\hat{\mathrm{h}}^{2}<0,4\right)$ e ácido cafeico $\left(\hat{\mathrm{h}}^{2}<0,3\right)$. O conteúdo dos compostos e os valores dos parâmetros genéticos poderão subsidiar os programas de melhoramento da erva-mate.
\end{abstract}

Termos para indexação: Ilex paraguariensis, cafeína, ácido cafeico, ácido clorogênico, parâmetros genéticos, teobromina.

\section{Introduction}

Mate (Ilex paraguariensis St. Hil.), a species of the family Aquifoliaceae, is native to southern South America, and almost $80 \%$ of its natural occurrence is in the five southernmost states of Brazil, where it shows relevant economic and social importance.
Methylxanthines and phenolic compounds are the main chemical compounds found in mate. The main methylxanthine is caffeine $(0.89-1.73 \%)$, followed by theobromine, and small amounts of theophylline (Cardozo Junior et al., 2007). Among the phenolic compounds, chlorogenic acids (CGA) are the best 
known (Alikaridis, 1987). Biological properties such as antioxidant (Schinella et al., 2000), eupeptic, choleretic (Gorzalczany et al., 2001), and hypocholesterolemic (Gugliucci, 1996) have been associated with the chemical compounds of mate.

The contents of these compounds are determined by plant origin, genetic and environmental variability, harvest time, and processing (Athayde et al., 2000). Contents also vary according to the seasons (Da Croce, 2002), varieties and progenies (Scherer et al., 2002; Cardozo Junior et al., 2007).

Estimation of genetic parameters is important for quantitative information of the genic action, to indicate the most appropriate selection scheme, and to estimate the selection progress (Resende, 2002a). The genetic control of a certain trait may be evaluated by its heritability, which corresponds to the proportion of the total variability of a genetic nature, or the ratio between the genetic variance and the total variance. The narrow sense heritability is important for sexual propagation and allows estimating the possibilities of gain of a character (Sturion, 1993).

Using the test applied in the present research, Sturion et al. (2004) observed that mate from the Barão de Cotegipe, RS, Quedas do Iguaçu, Cascavel, and Ivaí, PR, regions are the most productive. They also determined the narrow sense heritability at family mean level for tannins, phenolic compounds, and caffeine contents, ranging from medium to high, which indicates a good possibility of genetic gain by progeny selection.

There are few studies on the breeding of mate aiming at the improvement of the traits of its commercial products and, possibly, its biological properties.

The objective of this work was to evaluate the methylxanthines and phenolic compounds present in the leaves of 51 mate progenies (half sib-families) and to estimate genetic parameters, such as the variance coefficients and heritability.

\section{Materials and Methods}

Progenies were from five Brazilian geographical origins, as follow: Ivaí, PR - progenies 1, 3, 4, 5, 7, 8, 10, 11, 15, 21, 25, Barão de Cotegipe, RS - progenies $51,53,57,58,59,61,65,68,69,70$, Quedas do Iguaçú, PR, - progenies $80,81,84,86,87,88,91,92,93,100$, Pinhão, PR, - progenies 101, 102, 104, 105, 106, 107,
110, 121, 122, 125 and Cascavel, PR, - progenies 151, $152,155,157,159,162,163,164,165,171$. They were grown in Ivaí, state of Paraná at $25^{\circ} 01^{\prime} \mathrm{S}, 50^{\circ} 47^{\prime} \mathrm{W}$ and 650-750 m altitude, in March 1997.

The Ivaí climate is Cfb-type, mesothermal humid subtropical. Warm summers and infrequent frosts occur in this region, and there is a tendency to rain concentration in the summer and without a well-defined dry season (Iapar, 2008). The soil is Latossolo Vermelho distrófico (Rhodic Hapludox) comprising 72\% clay and $4 \%$ slope (Santos et al., 2006).

Experiments were arranged in a randomized block design in ten replications with six plants in a $3 \times 2 \mathrm{~m}$ spacing. Progeny selection was randomized without hierarchic arrangement within each geographical origin. The plants were hand harvested in August 2004 at a leaf age of 12 months; in November 2004, leaf age of 18 months, and in June 2005, leaf age of 24 months.

The samples analyzed correspond to a combined half-sib family test of the geographical origins and progenies. Provenances with high leaf mass production were selected. Leaves $(100 \mathrm{~g})$ from the medium third of the plant were collected and immediately brought to the laboratory. Each sample was boiled in water for $10 \mathrm{~s}$; the green and clean leaves were separated and dried in a forced draft oven $\left(45^{\circ} \mathrm{C}, 48\right.$ hours $)$. Afterwards, the leaves were ground, placed on paper, wrapped with plastic, and refrigerated until analysis.

The methylxanthines caffeine and theobromine as well as the phenolic acids chlorogenic and caffeic were extracted from the leaves $(1 \mathrm{~g})$ by maceration in $50 \mathrm{~mL}$ methanol:water (70:30, v/v) for analysis (Filip et al., 2001). The extracts were filtered using $0.45 \mu \mathrm{m}$ nylon filters and chromatographed on a Shimadzu Mod. SCL-10A, (Shimadzu, Kyoto, Japan) high performance liquid chromatography (HPLC) system. A 5- $\mu \mathrm{m}$ Supelcosil LC-18 (Sigma-Aldrich Inc., USA), $4.6 \times 250 \mathrm{~mm}$ analytical column was used. The column was maintained at $30^{\circ} \mathrm{C}$ using the CTO-10AS (Shimadzu, Kyoto, Japan) HPLC integrated oven. The solvent system consisted of acidulated water with $0.3 \%$ acetic acid, and methanol. The solvents were run at a flow rate of $1.0 \mathrm{~mL} \mathrm{~min}^{-1}$ using the following linear gradient: $15 \%$ to $20 \%$ methanol for $20 \mathrm{~min}, 20 \%$ to $85 \%$ methanol for $5 \mathrm{~min}$, and $85 \%$ methanol for $5 \mathrm{~min}$. Detection was monitored at $265 \mathrm{~nm}$ for caffeine and theobromine, and at $325 \mathrm{~nm}$ for caffeic and 
chlorogenic acids using an SPD-10A UV-vis detector (Shimadzu, Kyoto, Japan) coupled to the chromatograph. All samples were run in duplicate. Chromatographic peaks were identified by comparing retention times with those of caffeine, theobromine, and chlorogenic and caffeic acid standards (Sigma Chemical Co., St. Louis, USA) recorded in the same conditions. All reagents used were of the purest grade available or chromatographic grade. Calibration curves were obtained through the mentioned standards after dilution in the mobile phase. Linearity was determined by regression and precision as well as accuracy were determined using the variation coefficient $(\mathrm{CV}<3 \%)$. The correlation coefficients obtained were $r^{2}=0.9999$ for caffeine, $r^{2}=0.9976$ for theobromine, $r^{2}=0.9997$ for chlorogenic acid, and $r^{2}=0.9995$ for caffeic acid.

The genetic and phenotypic parameters were estimated by the restricted maximum likelihood (REML) method for variance component estimation and the best linear unbiased prediction (BLUP) procedure for breeding value prediction and genetic selection. The analyses were performed using the Selegen REML/BLUP software (Resende, 2002b; Missio et al., 2004; Chiorato et al., 2008). This Model includes random block experiments, half-sib progenies, several plants per plot, and several populations. In the individual analysis by trial, the linear model applied to the progeny trial data was:

$$
\mathrm{y}=\mathrm{Xb}+\mathrm{Za}+\mathrm{Wc}+\mathrm{e},
$$

where: $y, b, a, c$ and e are data vector, block effects (fixed), additive genetic effects (random), plot effects (random), and random error effects, respectively; $\mathrm{X}, \mathrm{Z}$ and $\mathrm{W}$ : incidence matrices for $\mathrm{b}, \mathrm{a}$, and $\mathrm{c}$, respectively.

Distributions and structures of means and variances:

$\mathrm{y} \mid \mathrm{b}, \mathrm{V} \sim \mathrm{N}(\mathrm{Xb}, \mathrm{V})$

$\mathrm{a} \mid \mathrm{A}, \hat{\sigma}_{\mathrm{a}}^{2} \sim \mathrm{N}\left(0, \mathrm{~A} \sigma_{\mathrm{a}}^{2}\right)$

$\mathrm{c} \mid \hat{\sigma}_{\mathrm{c}}^{2} \sim \mathrm{N}\left(0, \mathrm{I} \sigma_{\mathrm{c}}^{2}\right)$

$\mathrm{e} \mid \hat{\sigma}_{\mathrm{e}}^{2} \sim \mathrm{N}\left(0, \mathrm{I} \sigma_{\mathrm{e}}^{2}\right)$

The covariances among all random effects of the model were considered zero. Thus:

$\mathrm{E}\left[\begin{array}{c}\mathrm{y} \\ \mathrm{a} \\ \mathrm{c} \\ \mathrm{e}\end{array}\right]=\left[\begin{array}{c}\mathrm{Xb} \\ 0 \\ 0 \\ 0\end{array}\right]$ and $\operatorname{Var}\left[\begin{array}{c}\mathrm{y} \\ \mathrm{a} \\ \mathrm{c} \\ \mathrm{e}\end{array}\right]=\left[\begin{array}{cccc}\mathrm{V} & \mathrm{ZG} & \mathrm{WC} & \mathrm{R} \\ \mathrm{GZ} & \mathrm{G} & 0 & 0 \\ \mathrm{CW}^{\prime} & 0 & \mathrm{C} & 0 \\ \mathrm{R} & 0 & 0 & \mathrm{R}\end{array}\right]$, where:

$\mathrm{G}=\mathrm{A} \hat{\sigma}_{\mathrm{a}}^{2}$

$\mathrm{R}=\mathrm{I} \hat{\sigma}_{\mathrm{c}}^{2}$

$\mathrm{C}=\mathrm{I} \hat{\sigma}_{\mathrm{e}}^{2}$

$\mathrm{V}=\mathrm{ZAG} \hat{\sigma}_{\mathrm{a}}^{2} \mathrm{Z}^{\prime}+\mathrm{WI} \hat{\sigma}_{\mathrm{c}}^{2} \mathrm{~W}^{\prime}+\mathrm{I} \hat{\sigma}_{\mathrm{c}}^{2}=\mathrm{ZGZ}^{\prime}+\mathrm{WCW}^{\prime}+\mathrm{R}$

Mixed model equations:

$\left[\begin{array}{ccc}X^{\prime} X & X^{\prime} Z & X^{\prime} W \\ Z^{\prime} X & Z^{\prime} Z+A^{-1} \lambda_{1} & Z^{\prime} W \\ W^{\prime} X & W^{\prime} Z & W^{\prime} W+I \\ \lambda_{2}\end{array}\right]\left[\begin{array}{c}\hat{b} \\ \hat{a} \\ \hat{c}\end{array}\right]=\left[\begin{array}{c}X^{\prime} y \\ Z^{\prime} y \\ W^{\prime} y\end{array}\right]$

where:

$\lambda_{1}=\hat{\sigma}_{\mathrm{e}}^{2} / \hat{\sigma}_{\mathrm{a}}^{2}=\left(1-\hat{\mathrm{h}}^{2}-\mathrm{c}_{\mathrm{plot}}^{2}\right) / \hat{\mathrm{h}}^{2}$

$\lambda_{2}=\hat{\sigma}_{\mathrm{e}}^{2} / \hat{\sigma}_{\mathrm{c}}^{2}=\left(1-\hat{\mathrm{h}}^{2}-\mathrm{c}_{\mathrm{plot}}^{2}\right) / \mathrm{c}_{\text {plot }}^{2}$

$\hat{\mathrm{h}}^{2}=\hat{\sigma}_{\mathrm{a}}^{2} /\left(\hat{\sigma}_{\mathrm{a}}^{2}+\hat{\sigma}_{\mathrm{c}}^{2}+\hat{\sigma}_{\mathrm{e}}^{2}\right)$

is the narrow-sense individual heritability in the block;

$\mathrm{c}_{\mathrm{plot}}^{2}=\hat{\sigma}_{\mathrm{c}}^{2} /\left(\hat{\sigma}_{\mathrm{a}}^{2}+\hat{\sigma}_{\mathrm{c}}^{2}+\hat{\sigma}_{\mathrm{e}}^{2}\right)$

is the coefficient of determination of plot effects;

$c_{\text {prov }}^{2}=\hat{\sigma}_{\text {prov }}^{2} /\left(\hat{\sigma}_{\mathrm{a}}^{2}+\hat{\sigma}_{\mathrm{c}}^{2}+\hat{\sigma}_{\mathrm{e}}^{2}\right)$,

is the coefficient of determination of provenance effect; $\hat{\sigma}_{\mathrm{a}}^{2}$ is the additive genetic variance; $\hat{\sigma}_{\mathrm{c}}^{2}$ is the variance among plots; $\hat{\sigma}_{\mathrm{e}}^{2}$ is the residual variance; $\mathrm{A}$ is the additive genetic correlation matrix among individuals under evaluation.

The REML estimators for variance components using the expectation-maximization (EM) algorithm were:

$\hat{\sigma}_{e}^{2}=\left(y^{\prime} y-\hat{b}^{\prime} X^{\prime} y-\hat{a}^{\prime} Z^{\prime} y-\hat{c}^{\prime} W^{\prime} y\right) /[N-r(x)]$

$\hat{\sigma}_{\mathrm{a}}^{2}=\left[\hat{\mathrm{a}}^{\prime} \mathrm{A}^{-1}-\hat{\mathrm{a}}+\hat{\sigma}_{\mathrm{e}}^{2} \operatorname{tr}\left(\mathrm{A}^{-1} \mathrm{C}^{22}\right)\right] / \mathrm{q}$

$\hat{\sigma}_{\mathrm{c}}^{2}=\left(\hat{\mathrm{c}}^{\prime} \mathrm{c}+\hat{\sigma}_{\mathrm{e}}^{2} \operatorname{tr} \mathrm{C}^{33}\right) / \mathrm{s}$

where: $\operatorname{tr}$ is the trace operator of a matrix; $r(x)$ is the rank of matrix $\mathrm{X}$; $\mathrm{N}-\mathrm{r}(\mathrm{x})$ is the error degrees of freedom; $q$ is the number of individuals; $s$ is the number of plots; $\mathrm{N}$ is the total number of data; $\mathrm{C}^{22}$ and $\mathrm{C}^{33}$ are derived from the inverse of the coefficient matrix of 
the mixed model equations. CVgi $\left.\%=100\left[\left(\hat{\sigma}_{a}^{2}\right)^{1 / 2} / \hat{\mu}\right)\right]$ is the coefficient of individual additive genetic variance; $\operatorname{CVgp} \%=100\left[\left(\hat{\sigma}_{\mathrm{a}}^{2} / 4\right)^{1 / 2} / \hat{\mu}\right]$ is the coefficient of additive genetic variance between progenies, $\mathrm{CVe} \%=100\left\{\left[\left(0.75 \hat{\sigma}_{\mathrm{a}}^{2}+\hat{\sigma}_{\mathrm{e}}^{2}\right) / \mathrm{n}+\hat{\sigma}_{\mathrm{c}}^{2}\right]^{1 / 2} / \hat{\mu}\right\}$ is the coefficient of experimental variation; and $\hat{\mu}$ is the mean estimate.

The data follow a normal distribution. The significance of the observed differences was evaluated by SISVAR package (Ferreira, 2008), using random block analysis and the Scott-Knott grouping test at 5\% probability. All analyses were performed in duplicate and the results are given as dry matter percentage $(\mathrm{w} / \mathrm{w})$.

\section{Results and Discussion}

The mean contents of caffeine and theobromine varied from $0.248 \%$ (progeny 106 ) to $1.663 \%$ (progeny 11 ) and from $0.106 \%$ (progeny 84 ) to $0.807 \%$ (progeny 121 ), respectively (Table 1). Based on statistical significance, eight groups stand out for caffeine content and seven for theobromine. Comparison of the caffeine and theobromine contents reveals a significant and inverse $\left(r^{2}=-0.841\right)$ correlation. The interesting fact verified in the present study is that mate progenies comprising low caffeine contents showed high theobromine contents, which was confirmed by the inverse correlation between these methylxanthines.

The chlorogenic and caffeic acid content varied from $1.365 \%$ (progeny 4) to $2.281 \%$ (progeny 102 ) and from $0.027 \%$ (progeny 59 ) to $0.037 \%$ (progenies 1, 58, 84 and 125), respectively (Table 1). Based on the Scott-Knott statistical grouping test, two distinct groups were defined for chlorogenic acid, one consisting of 22 progenies with $1.365-1.765 \%$ content and another consisting of 29 progenies with $1.775-2.281 \%$ content. In contrast, the results for caffeic acid revealed three distinct groups; the largest, containing 32 progenies $(<0.032 \%)$, the second, containing 13 progenies $(0.032-0.034 \%)$ and the third, containing six progenies $(0.036-0.037 \%)$.

The chlorogenic acid content results corroborate those of Filip et al. (2001), while caffeic acid contents are higher. Both chlorogenic and caffeic acids showed low concentrations in mate, and di-caffeoylquinic derivatives such as 3,4-DCQ, 3,5-DCQ, and 4,5-DCQ are predominant (Clifford \& Ramirez Martinez, 1990; Filip et al., 2001). The variability observed for the contents of these two phenolic acids is smaller than those of methylxanthines.

Table 2 shows the caffeine and theobromine contents and ratios in progenies from five Brazilian geographical origins that showed significant differences. Progenies from Pinhão, PR, had low caffeine and high theobromine contents relative to the other origins. Whereas

Table 1. Mean (\%, w/w) caffeine, theobromine, chlorogenic and caffeic acid contents in 51 mate (Ilex paraguariensis) progenies grown in Ivaí, PR, Brazil ${ }^{(1)}$.

\begin{tabular}{|c|c|c|c|c|}
\hline Progeny & Caffeine & Theobromine & Chlorogenic acid & Caffeic acid \\
\hline 106 & $0.248 \mathrm{a}$ & $0.764 \mathrm{~g}$ & $1.692 \mathrm{a}$ & $0.029 a$ \\
\hline 101 & $0.280 \mathrm{a}$ & $0.548 \mathrm{e}$ & $1.934 \mathrm{~b}$ & $0.030 \mathrm{a}$ \\
\hline 8 & $0.373 b$ & $0.496 \mathrm{e}$ & $1.936 \mathrm{~b}$ & $0.032 b$ \\
\hline 105 & $0.398 b$ & $0.588 \mathrm{e}$ & $2.253 b$ & $0.029 \mathrm{a}$ \\
\hline 25 & $0.406 b$ & $0.373 \mathrm{c}$ & $1.587 \mathrm{a}$ & $0.028 \mathrm{a}$ \\
\hline 102 & $0.476 \mathrm{~b}$ & $0.679 f$ & $2.281 \mathrm{~b}$ & $0.029 \mathrm{a}$ \\
\hline 121 & $0.477 \mathrm{~b}$ & $0.807 \mathrm{~g}$ & $1.828 \mathrm{~b}$ & $0.027 \mathrm{a}$ \\
\hline 15 & $0.490 \mathrm{~b}$ & $0.571 \mathrm{e}$ & $1.837 \mathrm{~b}$ & $0.027 \mathrm{a}$ \\
\hline 110 & $0.679 \mathrm{c}$ & $0.388 \mathrm{~d}$ & $1.918 b$ & $0.028 \mathrm{a}$ \\
\hline 107 & $0.697 \mathrm{c}$ & $0.512 \mathrm{e}$ & $1.946 \mathrm{~b}$ & $0.029 \mathrm{a}$ \\
\hline 10 & $0.745 \mathrm{c}$ & $0.453 \mathrm{~d}$ & $1.765 \mathrm{a}$ & $0.028 \mathrm{a}$ \\
\hline 104 & $0.793 \mathrm{c}$ & $0.515 \mathrm{e}$ & $1.809 \mathrm{~b}$ & $0.032 b$ \\
\hline 57 & $0.952 \mathrm{~d}$ & $0.198 \mathrm{a}$ & $2.036 \mathrm{~b}$ & $0.030 \mathrm{a}$ \\
\hline 4 & $0.967 \mathrm{~d}$ & $0.396 \mathrm{~d}$ & $1.365 \mathrm{a}$ & $0.030 \mathrm{a}$ \\
\hline 5 & $0.989 \mathrm{~d}$ & $0.215 \mathrm{a}$ & $2.036 b$ & $0.028 \mathrm{a}$ \\
\hline 68 & $1.033 \mathrm{~d}$ & $0.202 \mathrm{a}$ & $1.584 \mathrm{a}$ & $0.030 \mathrm{a}$ \\
\hline 51 & $1.037 \mathrm{~d}$ & $0.168 \mathrm{a}$ & $1.962 \mathrm{~b}$ & $0.034 b$ \\
\hline 21 & $1.041 \mathrm{~d}$ & $0.318 \mathrm{c}$ & $1.809 \mathrm{~b}$ & 0.029 \\
\hline 152 & $1.068 \mathrm{~d}$ & $0.243 b$ & $1.943 b$ & $0.030 \mathrm{a}$ \\
\hline 7 & $1.074 \mathrm{~d}$ & $0.402 d$ & $1.793 b$ & $0.031 \mathrm{a}$ \\
\hline 3 & $1.097 \mathrm{e}$ & $0.257 \mathrm{~b}$ & $1.536 \mathrm{a}$ & $0.028 \mathrm{a}$ \\
\hline 91 & $1.123 \mathrm{e}$ & $0.198 \mathrm{a}$ & $1.585 \mathrm{a}$ & $0.032 \mathrm{a}$ \\
\hline 65 & $1.130 \mathrm{e}$ & $0.133 \mathrm{a}$ & $2.047 b$ & $0.030 \mathrm{a}$ \\
\hline 69 & $1.139 \mathrm{e}$ & $0.118 \mathrm{a}$ & $1.631 \mathrm{a}$ & $0.034 b$ \\
\hline 1 & $1.174 \mathrm{e}$ & $0.163 \mathrm{a}$ & $1.567 \mathrm{a}$ & $0.037 \mathrm{c}$ \\
\hline 80 & $1.175 \mathrm{e}$ & $0.238 b$ & $1.870 \mathrm{~b}$ & $0.032 \mathrm{~b}$ \\
\hline 125 & $1.187 \mathrm{e}$ & $0.178 \mathrm{a}$ & $1.775 \mathrm{~b}$ & $0.037 \mathrm{c}$ \\
\hline 163 & $1.201 \mathrm{e}$ & $0.285 \mathrm{c}$ & $1.914 \mathrm{~b}$ & $0.030 \mathrm{a}$ \\
\hline 81 & $1.243 \mathrm{f}$ & $0.230 \mathrm{~b}$ & $2.003 b$ & $0.032 b$ \\
\hline 100 & $1.270 \mathrm{f}$ & $0.291 \mathrm{c}$ & $1.666 \mathrm{a}$ & $0.032 \mathrm{~b}$ \\
\hline 59 & $1.275 \mathrm{f}$ & $0.198 \mathrm{a}$ & $1.370 \mathrm{a}$ & $0.027 \mathrm{a}$ \\
\hline 157 & $1.283 \mathrm{f}$ & $0.148 \mathrm{a}$ & $1.539 \mathrm{a}$ & $0.028 \mathrm{a}$ \\
\hline 164 & $1.289 \mathrm{f}$ & $0.204 \mathrm{a}$ & $1.876 \mathrm{~b}$ & $0.031 \mathrm{a}$ \\
\hline 165 & $1.309 \mathrm{f}$ & $0.313 \mathrm{c}$ & $1.613 \mathrm{a}$ & $0.032 b$ \\
\hline 162 & $1.317 \mathrm{f}$ & $0.178 \mathrm{a}$ & $1.825 b$ & $0.029 \mathrm{a}$ \\
\hline 84 & $1.330 \mathrm{f}$ & $0.106 \mathrm{a}$ & $1.941 \mathrm{~b}$ & $0.037 \mathrm{c}$ \\
\hline 87 & $1.332 \mathrm{f}$ & $0.174 \mathrm{a}$ & $1.903 b$ & $0.032 b$ \\
\hline 53 & $1.333 \mathrm{f}$ & $0.233 b$ & $1.802 b$ & $0.029 \mathrm{a}$ \\
\hline 86 & $1.341 \mathrm{f}$ & $0.190 \mathrm{a}$ & $1.746 \mathrm{a}$ & $0.032 \mathrm{~b}$ \\
\hline 88 & $1.346 \mathrm{f}$ & $0.292 \mathrm{c}$ & $1.626 \mathrm{a}$ & $0.031 \mathrm{a}$ \\
\hline 122 & $1.351 \mathrm{f}$ & $0.161 \mathrm{a}$ & $1.613 \mathrm{a}$ & $0.030 \mathrm{a}$ \\
\hline 61 & $1.355 \mathrm{f}$ & $0.192 \mathrm{a}$ & $1.650 \mathrm{a}$ & $0.036 \mathrm{c}$ \\
\hline 93 & $1.355 \mathrm{f}$ & $0.229 b$ & $1.816 \mathrm{~b}$ & $0.029 \mathrm{a}$ \\
\hline 171 & $1.371 \mathrm{f}$ & $0.252 b$ & $1.793 b$ & $0.033 b$ \\
\hline 155 & $1.371 \mathrm{f}$ & $0.212 \mathrm{a}$ & $1.864 \mathrm{~b}$ & $0.032 b$ \\
\hline 58 & $1.419 \mathrm{~g}$ & $0.174 \mathrm{a}$ & $1.862 \mathrm{~b}$ & $0.037 \mathrm{c}$ \\
\hline 159 & $1.454 \mathrm{~g}$ & $0.178 \mathrm{a}$ & $1.737 \mathrm{a}$ & $0.028 \mathrm{a}$ \\
\hline 92 & $1.467 \mathrm{~g}$ & $0.147 \mathrm{a}$ & $1.722 \mathrm{a}$ & $0.029 \mathrm{a}$ \\
\hline 151 & $1.467 \mathrm{~g}$ & $0.200 \mathrm{a}$ & $1.656 \mathrm{a}$ & $0.030 \mathrm{a}$ \\
\hline 70 & $1.468 \mathrm{~g}$ & $0.255 b$ & $1.691 \mathrm{a}$ & $0.032 \mathrm{~b}$ \\
\hline 11 & $1.663 \mathrm{~h}$ & $0.184 \mathrm{a}$ & $1.735 \mathrm{a}$ & $0.036 \mathrm{c}$ \\
\hline Mean \pm SD & $1.076 \pm 0.521$ & $0.297 \pm 0.243$ & $1.790 \pm 0.84$ & $0.031 \pm 0.028$ \\
\hline
\end{tabular}

${ }^{(1)}$ Means followed by different letters in the same column are significantly different by Scott-Knott test, at 5\% probability. 
progenies from Ivaí, PR, presented intermediate values, progenies from Barão de Cotegipe, RS, Quedas do Iguaçu, PR, and Cascavel, PR, had high caffeine and low theobromine contents. Caffeine/theobromine ratios varied from 1.28, at Pinhão, to 6.49 , at Barão de Cotegipe. A similar trend was found by Cardozo Junior et al. (2007) in 16 mate progenies from four Brazilian geographical origins grown in three different locations. The analyses of caffeine and theobromine contents of all progenies here reported reveals a variability that may be exploited in breeding programs. The presence of caffeine and theobromine, which are responsible for the stimulating and tonic effects of mate (Cardozo Junior et al., 2007), represents a feasible indicator for the selection of progenies and the development of alternative mate products. Furthermore, progenies comprising very high caffeine and theobromine contents might also be used in improvement programs to obtain raw materials with predefined chemical compositions.

The chlorogenic acid content in Pinhão progenies was significantly higher than the others. The caffeic acid contents ranged from 0.030 to $0.0319 \%$ among origins (Table 2 ).

In general, the coefficient of determination of the plot effects $\left(\mathrm{c}_{\mathrm{plot}}^{2}\right)$, which indicates the environmental variations between plots, was low for caffeine and theobromine (Table 3). The coefficient values of additive genetic variation for individuals (CVgi\%), which express the genetic variation of the evaluated compound contents, ranged from 25.82 to $38.91 \%$ for caffeine, and from 37.33 to $68.05 \%$ for theobromine, indicating a potential for character improvement. The coefficient values of the additive genetic progeny variation (CVgp\%), which quantifies the genetic variation between progenies, ranged from 19.44 to $29.03 \%$, for caffeine, and from 18.66 to $46.77 \%$, for theobromine.

There was a change in $\mathrm{c}_{\text {plot }}^{2}$ from intermediate to high values for both chlorogenic and caffeic acids, which may be due to environmental variations between plots. The CVgi\% values varied from 11.55 to $16.07 \%$ and from 2.18 to $32.38 \%$ for chlorogenic and caffeic acids, respectively. The $\mathrm{CVgp} \%$ values ranged from 5.77 to

Table 2. Mean (\%,w/w) caffeine, theobromine, chlorogenic and caffeic acid contents in mate (Ilex paraguariensis) progenies from five origins ${ }^{(1)}$.

\begin{tabular}{lccccc}
\hline Provenance & Caffeine & Theobromine & Caffeine/ theobromine ratio & Chlorogenic acid & Caffeic acid \\
\hline Pinhão & $0.659 \mathrm{a}$ & $0.514 \mathrm{~d}$ & 1.28 & $1.905 \mathrm{~b}$ & $0.0300 \mathrm{a}$ \\
Ivaí & $0.911 \mathrm{~b}$ & $0.348 \mathrm{c}$ & 2.62 & $1.724 \mathrm{a}$ & $0.0304 \mathrm{a}$ \\
Barão de Cotegipe & $1.214 \mathrm{c}$ & $0.187 \mathrm{a}$ & 6.49 & $1.764 \mathrm{a}$ & $0.0319 \mathrm{~b}$ \\
Quedas do Iguaçu & $1.298 \mathrm{~d}$ & $0.209 \mathrm{~b}$ & 6.21 & $1.788 \mathrm{a}$ & $0.0318 \mathrm{~b}$ \\
Cascavel & $1.313 \mathrm{~d}$ & $0.221 \mathrm{~b}$ & 5.94 & $1.776 \mathrm{a}$ & $0.0303 \mathrm{a}$ \\
\hline
\end{tabular}

${ }^{(1)}$ Means followed by different letters in the same column are significantly different by Scott-Knott test, at $5 \%$ probability.

Table 3. Variance and determination coefficients of caffeine, theobromine, chlorogenic and caffeic acid contents in mate (Ilex paraguariensis) progenies grown in Ivaí, PR, Brazil ${ }^{(1)}$.

\begin{tabular}{|c|c|c|c|c|c|c|}
\hline Compound & Leaf age (months) & $\mathrm{C}_{\text {plot }}^{2}$ & $\mathrm{C}_{\text {prov }}^{2}$ & CVgi $\%$ & $\mathrm{CVgp} \%$ & $\mathrm{CVe}$ \\
\hline \multirow[t]{3}{*}{ Caffeine } & 12 & 0.0909 & 0.2812 & 38.91 & 29.03 & 23.11 \\
\hline & 18 & 0.0454 & 0.3093 & 29.61 & 19.44 & 15.11 \\
\hline & 24 & 0.1305 & 0.2359 & 25.82 & 23.35 & 20.59 \\
\hline \multirow[t]{3}{*}{ Theobromine } & 12 & 0.1425 & 0.3712 & 68.05 & 46.77 & 47.03 \\
\hline & 18 & 0.0102 & 0.2381 & 37.33 & 18.66 & 15.38 \\
\hline & 24 & 0.2528 & 0.2020 & 41.18 & 31.30 & 40.03 \\
\hline \multirow[t]{3}{*}{ Chlorogenic acid } & 12 & 0.5208 & 0.0012 & 11.55 & 5.77 & 27.39 \\
\hline & 18 & 0.5146 & 0.0004 & 15.07 & 7.54 & 25.66 \\
\hline & 24 & 0.3764 & 0.0044 & 16.07 & 8.03 & 17.54 \\
\hline \multirow[t]{3}{*}{ Caffeic acid } & 12 & 0.3082 & 0.0005 & 2.18 & 1.09 & 3.03 \\
\hline & 18 & 0.4014 & 0.0003 & 32.38 & 16.19 & 43.25 \\
\hline & 24 & 0.5969 & 0.0057 & 19.64 & 9.82 & 75.58 \\
\hline
\end{tabular}

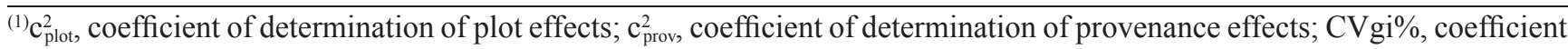
of additive genetic variance of individuals; $\mathrm{CVgp} \%$, coefficient of additive genetic variance between progeny; $\mathrm{CVe}$, coefficient of experimental variation. 
$8.03 \%$ for chlorogenic acid, and from 1.09 to $16.19 \%$ for caffeic acid (Table 3 ).

Moreover, the CVgi\%, CVgp\%, and heritability values were lower than those of the methylxanthines. Montagnon et al. (1998) obtained similar heritability estimates for chlorogenic acid in Coffea canephora, which correlated with the phenotypic characteristics of the species

The estimated coefficient of narrow sense heritability $\left(\hat{h}^{2}\right)$ of caffeine and theobromine in progenies grown in the Ivaí, PR, region were high and associated with low standard deviation, which is related to the estimated accuracy (Table 4). The $\hat{h}^{2}$ of chlorogenic and caffeic acids varied from low to intermediate values.

Additive genetic variance $\left(\hat{\sigma}_{\mathrm{a}}^{2}\right)$ is one of the most important components of variance to be determined. It demonstrates the potential of the population for improvement of a character by sexual reproduction. These findings are of particular interest because the lower $\mathrm{c}_{\text {plot }}^{2}$ values for caffeine (Table 3 ) indicate that possible environmental differences between plots, mainly in soil characters, did not significantly influence the total variability composition. As noted in the present work (Table 4), the heritability estimates for caffeine and theobromine were high and associated with low standard deviation, which is related to the estimated accuracy. In the case of high heritability, the genetic variation represents most of the phenotypic variation in response to environmental variation (Resende, 2002b). The enhanced high heritability values for caffeine and theobromine indicate high genetic control in the conditions evaluated. A high heritability value indicates a good possibility of genetic gain with selection (Missio et al., 2004). High heritability values for caffeine were also observed in mate progenies from the Missiones region, Argentina (Scherer et al., 2002).

Table 4. Estimates of narrow sense heritability $\left(\hat{\mathrm{h}}^{2}\right)$ of caffeine, theobromine, chlorogenic and caffeic acids in mate (Ilex paraguariensis) progenies grown in Ivaí, PR, Brazil.

\begin{tabular}{llll}
\hline \multirow{2}{*}{ Compound } & \multicolumn{3}{c}{$\hat{\mathrm{h}}^{2}$} \\
\cline { 2 - 4 } & 12 months & 18 months & 24 months \\
\hline Caffeine & $0.65 \pm 0.21$ & $0.60 \pm 0.22$ & $0.55 \pm 0.18$ \\
Theobromine & $0.55 \pm 0.20$ & $0.64 \pm 0.26$ & $0.50 \pm 0.18$ \\
Chlorogenic acid & $0.11 \pm 0.10$ & $0.20 \pm 0.14$ & $0.39 \pm 0.20$ \\
Caffeic acid & $0.21 \pm 0.15$ & $0.27 \pm 0.17$ & $0.04 \pm 0.07$ \\
\hline
\end{tabular}

Schneider et al. (2006) have reported on the quantification of methylxanthines, phenolic compounds and saponins in mate grown in Argentina. Scherer et al. (2002) verified high saponin index heritability values (narrow sense heritability = 0.59 and broad sense heritability $=0.86$ ) for the progenies evaluated, which were compatible to those of caffeine. Their findings indicate the possibility of applying selection strategies to modify the mate saponin content in a manner similar to that used for caffeine and theobromine. Previous studies in native mate populations revealed high genetic variability.

This high intrapopulation variability may be related to the reproductive trait (allogamy), which permits intense gene flow between populations (Wendt et al., 2007). In addition, Cansian et al. (2008) also found that mate intrapopulation variances were larger than the interpopulation ones. In studies on the provenance and progeny test in the Ivaí region, Sturion et al. (2004) concluded that high genetic gains might be obtained with the selection of individuals based on genetic values of leaf biomass weight.

\section{Conclusions}

1. Mate progenies show significant differences in caffeine, theobromine, chlorogenic and caffeic acid contents.

2. Caffeineand theobromine contents in the progenies varied significantly from different geographical origins.

3. The narrow-sense individual heritability in the block $\left(\hat{\mathrm{h}}^{2}\right)$, the coefficient of individual additive genetic variance (CVgi\%) as well as the coefficient of additive genetic variance between progenies $(\mathrm{CVgp} \%)$ values of both caffeine and theobromine indicate a good possibility of genetic gain.

\section{Acknowledgements}

To Dalnei Neiverth and Afonso Oliszeski (Neiverth \& Cia Ltda - Chimarrão Bitumirim of Ivaí, PR) for the use of facilities, the collaboration in the facility setup, operation, and the evaluation of the combined mate origin and progeny tests. 


\section{References}

ALIKARIDIS, F. Natural constituents of Ilex species. Journal Ethnopharmacology, v.20, p.121-144, 1987.

ATHAYDE, M.L.; COELHO, G.C.; SCHENKEL, E.P. Caffeine and theobromine in epicuticular wax of Ilex paraguariensis A. St. Hil. Phytochemistry, v.55, p.853-857, 2000.

CANSIAN, R.L.; MOSSI, A.J.; MAZUTTI, M.; OLIVEIRA, J.V.; PAROUL, N.; DARIVA, C.; ECHEVERRIGARAY, S. Semi-volatile compounds variation among brazilian populations of Ilex paraguariensis St. Hil. Brazilian Archives of Biology and Technology, v.51, p.175-181, 2008.

CARDOZO JUNIOR, E.L.; FERRARESE-FILHO, O.; CARDOZO FILHO, L.; FERRARESE, M.L.L.; DONADUZZI, C.M.; STURION, J.A. Methylxanthines and phenolic compounds in mate (Ilex paraguariensis St. Hil.) progenies grown in Brazil. Journal of Food Composition and Analysis, v.20, p.553-558, 2007.

CHIORATO, A.F.; CARBONELL, S.A.M.; DIAS, L.A.S.; RESENDE, M.D.V. Prediction of genotypic values and estimation of genetic parameters in common bean. Brazilian Archives of Biology and Technology, v.51, p.465-472, 2008.

CLIFFORD, M.N.; RAMIREZ MARTINEZ, J. Chlorogenic acids and purine alkaloids contents of mate (Ilex paraguariensis) leaf and beverage. Food Chemistry, v.35, p.13-21, 1990.

DA CROCE, D.M. The physical and chemical characteristics of tea (Ilex paraguariensis St Hil) in Santa Catarina state. Ciência Florestal, v.12, p.107-113, 2002.

FERREIRA, D.F. SISVAR: um programa para análises e ensino de estatística. Revista Científica Symposium, v.6, p.36-41, 2008.

FILIP, R.; LÓPEZ, P.; GIBERTI, G.; COUSSIO, J.; FERRARO, G. Phenolic compounds in seven South American Ilex species. Fitoterapia, v.72, p.774-778, 2001.

GORZALCZANY, S.; FILIP, R.; ALONSO, M.R.; MIÑO, J.; FERRARO, G.E.; ACEVEDO, C. Choleretic effect and intestinal propulsion of 'mate' (Ilex paraguariensis) and its substitutes or adulterants. Journal of Ethnopharmacolgy, v.75, p.291-294, 2001.

GUGLIUCCI, A. Antioxidant effects of Ilex paraguariensis: Induction of decreased oxidability of human LDL in vivo. Biochemical and Biophysical Research Communications, v.224, p.338-344, 1996.

IAPAR. Cartas Climáticas do Estado do Paraná. Available at: $\quad<$ http://www.iapar.br/Sma/Cartas_Climaticas/Classificacao_ Climatica.htm>. Accessed on: 9 Sept. 2008.
MISSIO, R.F.; DIAS, L.A.S.; MORAES, M.L.T.; RESENDE, M.D.V. Selection of Pinus caribaea var. bahamensis progênies based on the predicted genetic value. Crop Breeding and Applied Biotechnology, v.4, p.399-407, 2004.

MONTAGNON, C.; GUYOT, B.; CILAS, C.; LEROY, T. Genetic parameters of several biochemical compounds from green coffee, Coffea canephora. Plant Breeding, v.117, p.576-578, 1998.

RESENDE, M.D.V. Genética biométrica e estatística no melhoramento de plantas perenes. Brasília: Embrapa Informação Tecnológica, 2002a. 975p.

RESENDE, M.D.V. Software Selegen-REML/BLUP. Colombo: Embrapa Florestas, 2002b. (Embrapa Florestas. Documentos, 77).

SANTOS, H.G. dos; JACOMINE, P.K.T.; ANJOS, L.H.C. dos; OLIVEIRA, V.A. de; OLIVEIRA, J.B. de; COELHO, M.R.; LUMBRERAS, J.F.; CUNHA, T.J.F. (Ed.). Sistema brasileiro de classificação de solos. Rio de Janeiro: Embrapa Solos, 2006. $306 \mathrm{p}$.

SCHERER, R.; URFER, P.; MAYOL, M.R.; BELINGHERI, L.D.; MARX, F.; JANSSENS, M.J.J. Inheritance studies of caffeine and theobromine content of Mate (Ilex paraguariensis) in Misiones, Argentina. Euphytica, v.126, p.203-210, 2002.

SCHNEIDER, E.; SCHERER, R.A.; JANSSENS, M.J.J. Mate from Argentina: production, sensory analysis, use. Deutsche Lebensmittel Rundschau, v.102, p.313-318, 2006.

SCHINELLA, G.R.; TROIANI, G.; DÁVILA, V.; BUSCHIAZZO, P.M. de; TOURNIER, H.A. Antioxidant effects of an aqueous extract of Ilex paraguariensis. Biochemical and Biophysical Research Communications, v.269, p.357-360, 2000.

STURION, J.A. Variação genética de características de crescimento e de qualidade da madeira em progênies de Eucalyptus viminalis Labill. 1993. 150p. Tese (Ph.D.) Universidade Federal do Paraná, Curitiba.

STURION, J.A.; CORREA, G.; RESENDE, M.D.V. de; CARDOZO JUNIOR, E.L.; DONADUZZI, C.M. Controle genético dos teores de polifenóis totais, taninos e cafeína em progênies de erva-mate (Ilex paraguariensis St. Hil.) cultivadas em três classes de solos. Colombo: Embrapa Florestas, 2004. (Embrapa Florestas. Boletim de pesquisa e desenvolvimento, 16).

WENDT, S.N.; SOUSA, V.A.; QUOIRIN, M.; SEBBENN, A.M.; MAZZA, M.C.; STURION, J.A. Caracterização genética de procedências e progênies de Ilex paraguariensis St. Hil. utilizando marcadores RAPD. Scientia Forestalis, v.73, p.47-53, 2007.

Received on October 19, 2009 and accepted on December 30, 2009 